\title{
The Arg72Pro Polymorphism of TP53 in Croatian Population ${ }^{\dagger}$
}

\author{
Arijana Zorić, ${ }^{a}$ Anđela Horvat, ${ }^{\mathrm{a}}$ Melita Balija, ${ }^{\mathrm{b}}$ and Neda Slade ${ }^{\mathrm{a}, *}$ \\ ${ }^{\mathrm{a}}$ Division of Molecular Medicine, Ruđer Bošković Institute, Bijenička c. 54, HR-10000 Zagreb, Croatia \\ ${ }^{\mathrm{b}}$ Croatian Institute of Transfusion Medicine, Petrova 3, HR-10000 Zagreb, Croatia
}

\begin{abstract}
Single nucleotide polymorphisms of TP53 gene in human populations are expected to cause perturbation of p53 function, and therefore could influence risk and/or progress of disease. There are differences in inducing apoptosis, cell cycle arrest, transcriptional activity, protein interactions between variants in codon 72 (Arg72Pro), although the association of polymorphism and risk of cancer is controversial. The aim of our study was to investigate the frequency of alleles and genotypes of Arg72Pro polymorphism in the ethnically homogenous Croatian population and to compare it with the worldwide populations. In a cohort of 576 participants the genotype frequencies of Arg/Arg, Arg/Pro and Pro/Pro are $54.34,38.71$ and $6.95 \%$, respectively. We statistically sorted the population of Croatia into the same group with other European populations and Caucasians from North America. This finding is important for the molecular pathways studies involved in disease as well as in pharmacogenetic studies. (doi: $10.5562 /$ cca1866)
\end{abstract}

Keywords: tumor suppressor gene $p 53, p 73, \mathrm{SNP}, \operatorname{Arg} 72 \mathrm{Pro}$

\section{INTRODUCTION}

TP53 is a tumor suppressor gene that governs cellular responses to a broad spectrum of stress (DNA damage, hypoxia, oncogenic stress) by inducing cell cycle arrest, apoptosis or senescence and plays a key role in the prevention of cancer development. Inactivation (mostly by mutations) of the p53 tumor suppressor is the single most common genetic defect in human cancer. ${ }^{1}$

Variations in DNA sequence that have been found in unaffected human populations are considered as polymorphisms. Generally, variations in the DNA sequences can affect the development of disease and response to therapy and are thought to be key enablers in realizing the concept of personalized medicine. Eighty five validated polymorphisms are found in TP53, most of which the functional consequences are still not clarified. Only few p53 polymorphisms have been determined to alter its biochemical and/or biological function, and to accomplish the cancer risk in population studies. Among all known polymorphisms, the one causing an Arg72Pro substitution is the most extensively studied. ${ }^{2}$

In human populations, codon 72 of TP53 has either the sequence CCC (encodes for proline) or CGC (which encodes arginine). Arg72Pro is located within the proline-rich domain in exon 4 of TP53 gene. ${ }^{2,3}$ Alt- hough both forms are considered as wild types and do not differ in the ability to bind to DNA, there are differences in mitochondrial localization, apoptosis, cell cycle progression, DNA repair, growth arrest and transcriptional transactivation. ${ }^{2}$ However, it was found that this polymorphism may affect the mutant p53 binding abilities and consequently functional properties of $\mathrm{p} 73 .{ }^{4}$ Arg72 increases the ability of p53 to bind the components of the transcriptional machinery, to activate transcription of target genes, to induce apoptosis, and to repress the transformation of primary cells. ${ }^{5}$ Unlike, Pro72 exhibits a lower apoptotic potential and causes an increased cellular arrest in G1 phase of the cell cycle. ${ }^{6-8}$ This is an important gain-of-function polymorphism at the cellular level.

These observations suggest that the p53 Arg72Pro polymorphism may influence the development of cancers which harbor wild-type p53 and possibly the ability of such tumors to respond to therapy and prognosis after cancer diagnosis, and longevity in general. However, the largest study of influence of Arg72Pro on cancer risk suggests that it is not associated with risk of cancer or any other disease but has effect on 5-year survival after cancer diagnosis and on general longevity. ${ }^{9}$ Pro/Pro homozygote and Arg/Pro heterozygote increased survival after cancer diagnosis for $13 \%$ and $9 \%$, respectively. ${ }^{9}$

\footnotetext{
$\dagger$ Presented at the $10^{\text {th }}$ Congress of the Croatian Society of Biochemistry and Molecular Biology held in Opatija, Croatia, September 15-18, 2010.

* Author to whom correspondence should be addressed. (E-mail: slade@irb.hr)
} 
The distribution of Arg72Pro polymorphism in the human population shows ethnic differences in allele expression. ${ }^{2,9-27}$ Whereas the Arg72Pro polymorphism is important for the tumor suppressor function of $\mathrm{p} 53 / \mathrm{p} 73$ proteins, we investigated the genotypic frequency of $\mathrm{p} 53$ codon 72 polymorphism in the healthy Croatian population, and compared the frequencies of Arg/Arg, Arg/Pro and Pro/Pro genotypes, as well as Arg and Pro alleles with the population of other countries worldwide.

\section{EXPERIMENTAL}

\section{Participants}

The prospective study of Croatian population included 576 (55 female, 521 male) unrelated individuals, ages 24-69, the healthy blood donors from Croatian Institute of Transfusion Medicine, Zagreb. All participants gave written informed consent. The Ethics Committee of Croatian Institute of Transfusion Medicine, Zagreb, approved the research.

\section{Genotyping of p53 Arg72Pro}

Genomic DNA was isolated from peripheral leukocytes by salting out method. ${ }^{28}$ To identify TP53 codon 72 polymorphisms the real-time PCR analysis for polymorphisms was performed using CFX96 Real-Time System (Bio Rad, Hercules, CA, USA) and TaqMan Pre-developed Assay Reagents for Allelic Discrimination C_2403545_10 (rs1042522) (Applied Biosystems, Foster City, CA, USA). For real-time PCR amplification, the reaction volume was $10 \mu \mathrm{l}$. No-template controls (NTC) and two positive controls $(\mathrm{C} / \mathrm{G})$ were run with each PCR reaction. The PCR reaction was carried out according to the manufacturer's protocol.

For allele discrimination, three clusters of points corresponding to the genotypes of $\mathrm{GG}, \mathrm{GC}$ or $\mathrm{CC}$ are expected in the analyses. If there is fluorescence for the reporter from allele 1 (Fam), the specimen genotype is CC. If there is fluorescence for the reporter from allele 2 (Vic) then the subject genotype is GG. If there is intermediate fluorescence from both reporters the genotype is GC. If no fluorescence is reported for either dye, then the PCR reaction failed.

\section{Statistical Analysis}

The Mann-Whitney-Wilcoxon test was used to compare the genotype distribution between the results of our research in Croatia and results of other researches from countries around the globe. Confidence level of $99 \%$ was used in statistical analysis.

\section{RESULTS}

\section{p53 Codon 72 Polymorphisms in Croatia}

In cohort of 576 healthy controls from Croatian general population, we have shown the distribution of a well known functional polymorphism in TP53 gene. The data are summarized in Table 1 . Forty $(6.95 \%)$ participants were Pro/Pro (C/C); 223 (38.71\%) were Pro/Arg (C/G), and 313 (54.34\%) were Arg/Arg homozygotes (G/G).

To identify the possible gender-related differences, the Arg72Pro polymorphism was compared separately in male and female participants within the Croatian population. Among 55 women there are only 2 (3.6 \%) Pro homozygotes (C/C), 22 (40\%) Pro/Arg $(\mathrm{C} / \mathrm{G})$ heterozygotes, and $31(56.4 \%)$ Arg homozygotes (G/G); comparing to $38(7.3 \%)$ of 521 male subjects Pro homozygotes (C/C), 201 (38.6 \%) Pro/Arg (C/G) heterozygotes, and $282(54.1 \%)$ Arg homozygotes $(\mathrm{G} / \mathrm{G})$ (Table 1). Since the distribution between genders is not equal (only 55 women out of 576 subjects) we were not able to do any statistical analysis.

\section{Statistical Analysis}

The aim of statistical analysis was to find "similarities" between populations of several countries worldwide and population of Croatia (Table 2). Therefore, we compared results for Croatian population with results from each of the following studies: China, Japan, Turkey, Greece, Nigeria, South Africa, India, USA, United Kingdom, Netherlands, Denmark, Italy, Germany, Portugal, Sweden and Slovakia.

Null hypothesis for each comparison made was that two sets of results are drawn from the same population (in a statistical sense) with confidence level $99 \%$. Verification of null hypothesis would mean that similarities of Arg/Pro distribution between the populations (in

Table 1. Distribution of p53 codon 72 polymorphism genotypes and allele frequencies in healthy participants in Croatia

\begin{tabular}{|c|c|c|c|c|c|c|c|c|c|c|}
\hline \multirow{2}{*}{ Participants } & \multicolumn{2}{|c|}{ Arg/Arg } & \multicolumn{2}{|c|}{ Arg/Pro } & \multicolumn{2}{|c|}{ Pro/Pro } & \multicolumn{2}{|c|}{ Arg allele } & \multicolumn{2}{|c|}{ Pro allele } \\
\hline & No. & $\%$ & No. & $\%$ & No. & $\%$ & No. & $\%$ & No. & $\%$ \\
\hline Total $(n=576)$ & 313 & 54.34 & 223 & 38.71 & 40 & 6.95 & 849 & 74.7 & 303 & 26.3 \\
\hline Female $(n=55)$ & 31 & 56.4 & 22 & 40 & 2 & 3.6 & 84 & 76.4 & 26 & 23.7 \\
\hline Male $(n=521)$ & 282 & 54.1 & 201 & 38.6 & 38 & 7.3 & 765 & 73.4 & 27 & 26.6 \\
\hline
\end{tabular}


Table 2. Statistical analysis of p53 codon 72 genotype in Croatia compared to the results of studies of different countries

\begin{tabular}{|c|c|c|c|c|c|}
\hline & \multicolumn{4}{|c|}{$n$} & \multirow{2}{*}{$z^{(\mathrm{a})}$} \\
\hline & total & Arg/Arg & Arg/Pro & Pro/Pro & \\
\hline $\mathrm{USA}^{(\mathrm{b})}$ & 308 & 168 & 112 & 28 & 0.19 \\
\hline Denmark $^{(b)}$ & 9.219 & 4.934 & 3.623 & 662 & 0.35 \\
\hline $\mathrm{UK}^{(\mathrm{b})}$ & 250 & 142 & 93 & 15 & 0.62 \\
\hline Netherlands $^{(b)}$ & 158 & 91 & 58 & 9 & 0.69 \\
\hline Italy ${ }^{(b)}$ & 140 & 83 & 47 & 10 & 0.83 \\
\hline Germany ${ }^{(b)}$ & 193 & 114 & 66 & 13 & 0.94 \\
\hline Portugal $^{(b)}$ & 145 & 92 & 40 & 13 & 1.41 \\
\hline Sweden $^{(b)}$ & 188 & 89 & 83 & 16 & 1.49 \\
\hline Slovakia ${ }^{(b)}$ & 330 & 200 & 113 & 17 & 1.67 \\
\hline China $^{(\mathrm{c})}$ & 45 & 10 & 26 & 9 & 4.01 \\
\hline $\mathrm{Japan}^{(\mathrm{c})}$ & 442 & 178 & 210 & 54 & 4.24 \\
\hline Turkey $^{(\mathrm{c})}$ & 87 & 24 & 49 & 14 & 4.37 \\
\hline Greece $^{(c)}$ & 51 & 10 & 32 & 9 & 4.41 \\
\hline Nigeria $^{(\mathrm{c})}$ & 59 & 7 & 25 & 27 & 7.25 \\
\hline $\operatorname{India}^{(c)}$ & 189 & 35 & 97 & 57 & 9.07 \\
\hline S. Africa ${ }^{(c)}$ & 340 & 32 & 147 & 161 & 15.25 \\
\hline Croatia & 576 & 313 & 223 & 40 & - \\
\hline
\end{tabular}

(a) Statistic for each research considered in statistical analysis.

(b) From the value of $z$ statistic, for these countries the null hypothesis is verified.

${ }^{\text {(c) }}$ For these countries the null hypothesis is dismissed with $99 \%$ confidence. a biological sense) of countries in which the studies were made are too significant to be considered accidental i.e. that it is worth looking into possible biological reasons for similarities.

According to obtained data, we divided the global population into two groups according to the "similarity" with Croatian population. The first "more similar" group consists mostly of European countries and Caucasian population of the USA. Only European populations of Greece and Turkey belong to another "more distinct" group together with Indian, Chinese and Japanese populations, as well as black population of Nigeria and South Africa.

\section{DISCUSSION}

Our study demonstrated the distribution of p53 polymorphism Arg72Pro in ethnically homogenous Caucasians of Croatian origin. This is the first direct comparison of the Arg/Pro genotype frequencies in Croatian population with the population of Europe and the world. The solely study done earlier reported only frequency of heterozigosity (36.8 \% of Arg/Pro genotype) using LOH method in 125 subjects. ${ }^{29}$ In our study we confirmed the same heterozigosity rate using real-time PCR analysis, but we also distinguished homozygotes, what is of importance for further studies.

Our results $(54.34 \%$ of Arg/Arg; $38.71 \%$ of Arg/Pro; $6.95 \%$ of Pro/Pro) are almost identical to

Table 3. Genotype and allele frequencies of p53 Arg72Pro polymorphism in different populations worldwide

\begin{tabular}{|c|c|c|c|c|c|c|c|c|c|}
\hline \multirow{2}{*}{ Country } & \multirow{2}{*}{$\begin{array}{l}\text { Total } \\
\text { cases }\end{array}$} & \multicolumn{2}{|c|}{ Arg/Arg } & \multicolumn{2}{|c|}{ Arg/Pro } & \multicolumn{2}{|c|}{ Pro/Pro } & \multicolumn{2}{|c|}{ Frequency } \\
\hline & & No. & $\%$ & No. & $\%$ & No. & $\%$ & Arg alelle / \% & Pro alelle / \% \\
\hline Croatia & 576 & 313 & 54.34 & 223 & 38.71 & 40 & 6.95 & 74.7 & 26.3 \\
\hline Turkey $^{13}$ & 87 & 24 & 27.59 & 49 & 56.32 & 14 & 16.09 & 55.75 & 44.25 \\
\hline Portugal $^{18}$ & 145 & 92 & 63.45 & 40 & 27.59 & 13 & 8.97 & 77.24 & 22.76 \\
\hline Greece $^{14}$ & 51 & 10 & 19.61 & 32 & 62.75 & 9 & 17.65 & 50.98 & 49.02 \\
\hline Italy ${ }^{22}$ & 140 & 86 & 61.43 & 47 & 33.57 & 7 & 5 & 78.21 & 21.79 \\
\hline Sweden $^{19}$ & 188 & 89 & 47.34 & 83 & 44.15 & 16 & 8.51 & 69.41 & 30.59 \\
\hline Slovakia ${ }^{20}$ & 330 & 200 & 60.61 & 113 & 34.24 & 17 & 5.15 & 77.7 & 22.3 \\
\hline Germany $^{23}$ & 193 & 114 & 59.07 & 66 & 34.2 & 13 & 6.74 & 76.17 & 23.83 \\
\hline Denmark $^{9}$ & 9219 & 4934 & 53.52 & 3623 & 39.3 & 662 & 7.18 & 73.17 & 26.83 \\
\hline $\mathrm{UK}^{21}$ & 250 & 142 & 56.8 & 93 & 37.2 & 15 & 6 & 75.4 & 24.6 \\
\hline $\mathrm{UK}^{24}$ & 246 & 155 & 63 & 79 & 32 & 12 & 5 & 61.4 & 38.6 \\
\hline $\mathrm{USA}^{27}$ & 308 & 168 & 54.55 & 112 & 36.36 & 28 & 9.09 & 72.73 & 27.27 \\
\hline China $^{(a)}$ & 45 & 10 & 22.22 & 26 & 57.78 & 9 & 20 & 51.11 & 49.89 \\
\hline Japan $^{(\mathrm{a})}$ & 44 & 18 & 40.91 & 16 & 36.36 & 10 & 22.73 & 59.09 & 49.91 \\
\hline Nigeria $^{(a)}$ & 59 & 7 & 11.86 & 25 & 42.37 & 27 & 45.76 & 33.05 & 66.95 \\
\hline South Africa ${ }^{10}$ & 340 & 32 & 9 & 147 & 43 & 161 & 48 & 31 & 69 \\
\hline India $^{26}$ & 189 & 35 & 18.52 & 97 & 51.32 & 57 & 30.16 & 44.18 & 55.82 \\
\hline $\operatorname{Iran}^{25}$ & 60 & 12 & 20 & 48 & 80 & 0 & 0 & 60 & 40 \\
\hline
\end{tabular}

\footnotetext{
(a) International HapMap Project.
} 
those reported for the Germany, Italy, Slovakia and other nearby countries, comparable in ethnicity and latitude. ${ }^{20,22,23}$

Arg72Pro polymorphism of TP53 gene appears to be very informative anthropological marker with characteristic ethnic pattern. Arg72Pro substitution has genotype frequencies in Europeans of $\sim 60,30$ and $10 \%$ for Arg/Arg, Arg/Pro and Pro/Pro, respectively. ${ }^{30}$ Caucasians differ from other ethnic groups, particularly Africans and African Americans which have much higher frequency of Pro allele. In an early study by Weston et $a l$. the significant difference between American Blacks and Whites was found: Pro allele was found in $61 \%$ of African Americans comparing to $35 \%$ of Caucasians. ${ }^{12}$ This study was followed by few studies of Beckman et $a l .{ }^{15,31}$ who showed a wide range variation of Pro allele from $17 \%$ in Sweden population to $63 \%$ in African Blacks in Nigeria. The majority of Caucasian individuals are carriers of the Arg allele. Generally, they claim the distribution of alleles differs from North to South. In favor to this premise is the study of the population of Southern Europe - in Turkey and Greece the Pro allele appears in more than $40 \%$ of subjects, ${ }^{13,14}$ comparing to other European countries where it appears at much lower frequency (Table 3, 21-30\%). Significant ethnic differences in the Arg72Pro polymorphism may arise from a natural selection of a particular allele or from the influence of various environmental factors, such as sunlight.

Polymorphism Arg72Pro was discovered as a difference in electrophoretic mobility of two versions of p53. ${ }^{32}$ There are significant functional differences between Arg and Pro allele. Arg allele of Arg72Pro polymorphism increases apoptosis, while Pro allele is connected with decreased apoptosis but increased G1 cell cycle arrest. ${ }^{6,8}$

Many studies were searching for involvement of Arg72Pro polymorphism in the risk of cancer including the risk of HPV-associated cancers, the prognosis of disease or response to therapy, longevity, hepatitis $\mathrm{C}$ and schizophrenia, in placental weight and in ageing., ${ }^{9,33-38}$ Today, it seems that Arg72Pro does not influence the risk of cancer, but Pro allele definitely increases median survival and longevity. ${ }^{39}$ Øersted et al. have found increased 5-year survival after diagnosis of cancer in persons carrying Pro allele. ${ }^{9}$ In a cohort of more than 9000 participants was found that Arg/Pro and Pro/Pro versus Arg/Arg have reduced mortality, which could result from a generally decreased aging process caused by decreased proapoptotic activity and increased cell cycle-arresting abilities of p53. Thus, Pro allele might be a benefit for a person experiencing any critical illness. ${ }^{9}$ Some authors suggest considering Arg72Pro polymorphism in the context of other genetic variations such as mutations in $p 53$ or other related genes. ${ }^{2}$ Thereby, only arginine expressing mutants in head and neck cancer patients caused poor response to chemotherapy and shorter survival. ${ }^{40}$

The limitation of our study was that we did not have enough female subjects to statistically confirm the finding that there are no sex differences. Nevertheless we didn't have equal distribution between genders to perform statistical analysis, there are no sex-related differences which was also reported previously. ${ }^{9}$

The advantage is the size (576 subjects) and homogeneity of the population. The basis for reliable studies of SNP association with common diseases is the large representative control group. In the history many studies on claiming the importance of this SNP for the risk of cancer were irreproducible studies, done in small groups. Large prospective studies of the general population are the gold-standard. ${ }^{39}$

Human studies are necessary to predict the effects on humans. A careful matching of the participants for ethnicity, among other factors, should be done in the studies investigating complex molecular pathways involved in carcinogenesis and other diseases as well as in pharmacogenetic studies. The large human studies, as the present study, are essential for modern and reliable biomedical research.

Acknowledgements. We thank Marko Zorić, BSc for statistical help and Maja Herak Bosnar, PhD for her helpful comments and suggestions. This work is supported by grant 0980982464-2391 by Ministry of Science, Education and Sports of the Republic of Croatia.

\section{REFERENCES}

1. P. Hainaut and M. Hollstein, Adv. Cancer Res. 77 (2000) 81-137.

2. C. Whibley, P. D. Pharoah, and M. Hollstein, Nat. Rev. Cancer 9 (2009) 95-107.

3. F. Toledo, C. J. Lee, K. A. Krummel, L. W. Rodewald, C. W. Liu, and G. M. Wahl, Mol. Cell. Biol. 27 (2007) 1425-1432.

4. M. C. Marin, C. A. Jost, L.A. Brooks, M. S. Irwin, J. O'Nions, J. A. Tidy, N. James, J. M. McGregor, C. A. Harwood, I. G. Yulug, K. H. Vousden, M. J. Allday, B. Gusterson, S. Ikawa, P. W. Hinds, T. Crook, and W. G. Kaelin Jr., Nat. Genet. 25 (2000) 47-54.

5. M. Thomas, A. Kalita, S. Labrecque, D. Pim, L. Banks, and G. Matlashewski, Mol. Cell. Biol. 19 (1999) 1092-100.

6. P. Dumont, J. I. Leu, A. C. Della Pietra III, D. L. George, and M. Murphy, Nat. Genet. 33 (2003) 357-365.

7. D. Bergamaschi, Y. Samuels, A. Sullivan, M. Zvelebil, H. Breyssens, A. Bisso, G. Del Sal, N. Syed, P. Smith, M. Gasco, T. Crook, and X. Lu, Nat. Genet. 38 (2006) 1133-1141.

8. D. Pim and L. Banks, Int. J. Cancer 108 (2004) 196-199.

9. D. D. Ørsted, S. E. Bojesen, A. Tybjaerg-Hansen, and B. G. Nordestgaard, J. Exp. Med. 204 (2007) 1295-1301.

10. R. J. Pegoraro, M. Moodley, L. Rom, R. Chetty, and J. Moodley, Int. J. Gynecol. Cancer 13 (2003) 444-449.

11. X. Jin, X. Wu, J. A. Roth, C. I. Amos, T. M. King, C. Branch, S. E. Honn, and M. R. Spitz, Carcinogenesis 16 (1995) 2205-2208.

12. A. Weston, L. S. Perrin, K. Forrester, R. N. Hoover, B. F. Trump, C. C. Harris, and N. E. Caporaso, Cancer Epidemiol. Biomarkers Prev. 1 (1992) 481-483. 
13. N. Buyru, J. Altinisik, M. Isin, and N. Dalay, Med. Sci. Monit. 14 (2008) CR493-497.

14. T. G. Kalemi, A. F. Lambropoulos, M. Gueorguiev, S. Chrisafi, K. T. Papazisis, and A. Kotsis, Cancer Lett. 222 (2005) 57-65.

15. G. Beckman, R. Birgander, A. Sjalander, N. Saha, P. A. Holmberg, A. Kivela, and L. Beckman, Hum. Hered. 44 (1994) 266-270.

16. D. Peixoto Guimaraes, S. Hsin Lu, P. Snijders, R. Wilmotte, R. Herrero, G. Lenoir, R. Montesano, C. J. Meijer, J. Walboomers, and P. Hainaut, Cancer Lett. 162 (2001) 231-235.

17. H. Y. Ngan, V. W. Liu and S. S. Liu, Br. J. Cancer 80 (1999) $1828-1829$

18. A. M. Santos, H. Sousa, R. Catarino, D. Pinto, D. Pereira, A. Vasconcelos, A. Matos, C. Lopes, and R. Medeiros, Cancer Genet. Cytogenet. 159 (2005) 143-147.

19. I. Zehbe, G. Voglino, E. Wilander, H. Delius, A. Marongiu, L. Edler, F. Klimek, S. Andersson, and M. Tommasino, Cancer Res. 61 (2001) 608-611.

20. P. Zubor, A. Stanclova, K. Kajo, J. Hatok, D. Klobusiakova, J. Visnovsky, and J. Danko, Oncology 76 (2009) 173-183.

21. S. Lanham, I. Campbell, P. Watt, and R. Gornall, Lancet 352 (1998) 1631-1632.

22. P. Tenti, N. Vesentini, M. Rondo Spaudo, R. Zappatore, P. Migliora, L. Carnevali, and G. N. Ranzani, Cancer Epidemiol. Biomarkers Prev. 9 (2000) 435-438.

23. K. Scheckenbach, O. Lieven, K. Gotte, U. Bockmuhl, R. Zotz, H. Bier, and V. Balz, Cancer Epidemiol. Biomarkers Prev. 13 (2004) 1805-1809.

24. A. N. Rosenthal, A. Ryan, R. M. Al-Jehani, A. Storey, C. A. Harwood, and I. J. Jacobs, Lancet 352 (1998) 871-872.

25. M. Kazemi, Z. Salehi, and R. J. Chakosari, Oncol. Res. 18 (2009) 25-30.

26. M. R. Pillai, S. Sreevidya, B. H. Pollock, P. G. Jayaprakash, and B. Herman, J. Cancer Res. Clin. Oncol. 128 (2002) 627-631.

27. K. F. Summersgill, E. M. Smith, H. L. Kirchner, T. H. Haugen, and L. P. Turek, Oral. Surg. Oral. Med. Oral. Pathol. Oral. Radiol. Endod. 90 (2000) 334-339.

28. S. A. Miller, D. D. Dykes, and H. F. Polesky, Nucleic Acids Res. 16 (1988) 1215.
29. J. Pavelić, M. H. Bosnar, and K. Gall-Trošelj, Eur. J. Cancer 34 (1998) 941-942.

30. E. V. Hogdall, C. K. Hogdall, L. Christensen, E. Glud, J. Blaakaer, J. E. Bock, J. Vuust, B. Norgaard-Pedersen, and S. K. Kjaer, Anticancer Res. 22 (2002) 1859-1864.

31. A. Sjalander, R. Birgander, N. Saha, L. Beckman, and G. Beckman, Hum. Hered. 46 (1996) 41-48.

32. N. Harris, E. Brill, O. Shohat, M. Prokocimer, D. Wolf, N. Arai, and V. Rotter, Mol. Cell. Biol. 6 (1986) 4650-4656.

33. A. Koushik, R. W. Platt, and E. L. Franco, Cancer Epidemiol. Biomarkers Prev. 13 (2004) 11-22.

34. F. Okada, T. Shiraki, M. Maekawa, and S. Sato, Cancer Lett. 172 (2001) 137-142.

35. S. J. Klug, M. Ressing, J. Koenig, M. C. Abba, T. Agorastos, S. M. Brenna, M. Ciotti, B. R. Das, A. Del Mistro, A. Dybikowska, A. R. Giuliano, Z. Gudleviciene, U. Gyllensten, A. L. Haws, A. Helland, C. S. Herrington, A. Hildesheim, O. Humbey, S. H. Jee, J. W. Kim, M. M. Madeleine, J. Menczer, H. Y. Ngan, A. Nishikawa, Y. Niwa, R. Pegoraro, M. R. Pillai, G. Ranzani, G. Rezza, A. N. Rosenthal, S. Roychoudhury, D. Saranath, V. M. Schmitt, S. Sengupta, W. Settheetham-Ishida, H. Shirasawa, P.J. Snijders, M. H. Stoler, A. E. Suarez-Rincon, K. Szarka, R. Tachezy, M. Ueda, A. G. van der Zee, M. von Knebel Doeberitz, M. T. Wu, T. Yamashita, I. Zehbe, and M. Blettner, Lancet Oncol. 10 (2009) 772-784.

36. D. van Heemst, S. P. Mooijaart, M. Beekman, J. Schreuder, A. J. de Craen, B. W. Brandt, P. E. Slagboom, and R. G. Westendorp, Exp. Gerontol. 40 (2005) 11-15.

37. R. Birgander, A. Sjalander, G. Beckman, and L. Beckman, Hum Hered. 46 (1996) 290-297.

38. F. W. Lung, B. C. Shu, W. T. Kao, C. N. Chen, Y. C. Ku, and D. S. Tzeng, BMC Med. Genet. 10 (2009) 147

39. S. E. Bojesen and B. G. Nordestgaard, Cell Cycle. 7 (2008) 158163.

40. D. Bergamaschi, M. Gasco, L. Hiller, A. Sullivan, N. Syed, G. Trigiante, I. Yulug, M. Merlano, G. Numico, A. Comino, M. Attard, O. Reelfs, B. Gusterson, A. K. Bell, V. Heath, M. Tavassoli, P. J. Farrell, P. Smith, X. Lu, and T. Crook, Cancer Cell 3 (2003) 387-402. 